http://kitaibelia.unideb.hu/

ISSN 2064-4507 (Online) • ISSN 1219-9672 (Print)

(C) Department of Botany, University of Debrecen, Hungary

23 (1): 8-14.; 2018

DOI: $10.17542 /$ kit.23.8

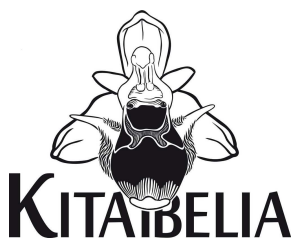

\title{
Adatok a Keszthelyi-hegység nőszőfúfajainak (Epipactis spp.) ismeretéhez
}

\author{
PACSAI Bálint \\ Pannon Egyetem GK Növénytudományi és Biotechnológiai Tanszék, H-8360 Keszthely, Festetics u. 7. \\ bpacsai@gmail.com
}

\section{Contribution to the distribution of Epipactis species in the Keszthely Mts}

\begin{abstract}
In this paper I present occurrence data of Epipactis species in the Keszthely Mts which were collected during the last four years. Ten species had literary or herbarium data from the area previously, all of them has been confirmed (Epipactis atrorubens, E. helleborine, E. leptochila, E. microphylla, E. moravica, E. muelleri, E. palustris, E. purpurata, E. nordeniorum, E. voethii) and another five species (Epipactis albensis, E. neglecta, E. peitzii, E. pontica, E. tallosii) furthermore a hybrid (Epipactis $\times$ reinekei) were found newly on the area.
\end{abstract}

Keywords: biotic data, distribution, floristics, Orchidaceae, rhizomatous orchids, Transdanubia

Összefoglalás - Jelen közleményben a Keszthelyi-hegységben 2014-2017 években tett terepbejárásaim során észlelt nőszőfü-előfordulásokat foglalom össze. A területről tíz nőszőfüfaj rendelkezett irodalmi vagy herbáriumi adatokkal, ezek előfordulását sikerült megerősíteni (Epipactis atrorubens, E. helleborine, E. leptochila, E. microphylla, E. moravica, E. muelleri, E. palustris, E. purpurata, E. nordeniorum, $E$. voethii) és a hegységre nézve további öt, eddig publikációban nem jelzett faj (Epipactis albensis, $E$. neglecta, E. peitzii, E. pontica, E. tallosii), illetve egy hibrid (Epipactis ×reinekei) került elő.

Kulcsszavak: biotikai adatok, Dunántúl, elterjedés, florisztika, Keszthelyi-hegység, Orchidaceae, rizómás orchideák

\section{Bevezetés}

A Keszthelyi-hegységre vonatkozó első botanikai adataink Kitaibel Pál 1799 évi baranyai útjáról származnak (vö. GoмBocz 1940), aki több, a területre jellemző növényfajt említ meg úti feljegyzéseiben. Az 1820-as években Wierzbicki Péter elkészíti a Keszthely környékén előforduló növényfajok részletes listáját (vö. BodNÁR 1957). A listán 950 faj szerepel, köztük az „Epipactis latifolia”, ami feltehetőleg nem a széleslevelü nőszőfüre, hanem sokkal inkább valószínű, hogy a fehér madársisakra (Cephalanthera damasonium (L.) Fritsch) vonatkozik, ahogy ezt az eredeti kézirat elavult nómenklatúráját helyesbítő Priszter Szaniszló jelzi (BoDNÁR 1957). A 19. század első harmadából származik az E. atrorubens (Hoffm.) Bess. egy „Keszthely” helymegjelöléssel ellátott herbáriumi lapja, melyet Hutter Mihály, Wierzbicki flóralistájának elkészítésében is segédkező gimnáziumi tanár gyűjtött. BoRBÁs (1900) már az E. helleborine (L.) Crantz-t, az E. palustris (L.) Crantz-t és az E. atrorubens-t egyaránt megemlíti, mint Keszthely, illetve az E. atrorubens esetében Gyenesdiás területén is előforduló fajokat. 1935-ben Vajda László a Büdöskúti-völgyben gyűjtött E. microphylla (Ehrh.) Sw.-t, ami a faj első felfede- 
zett előfordulása a hegységben. Ezután egészen az 1990-es évekig nem publikálták újabb nőszőfűfaj előfordulását a hegységből, annak ellenére, hogy a terület flórájáról több tanulmány is készült, melyek közül néhány részletesen foglalkozott az orchideafélékkel is (SzoDFRIDT 1960, FEKETE 1964, SzABó 1987), továbbá a hegységből származó herbáriumi lapok száma ez idő alatt tovább gyarapszik (MolnÁr et al. 2012). MolnÁr et al. (1995) már közli az E. purpurata Sm. előfordulását is, azonban ez az adat nem szerepel MoLNÁR (2011) összefoglaló művében. 1998-ban Takács Géza megtalálta a hegységben az E. leptochila (Godfery) Godferyt (MOLNÁR et al. 1998). Magyarország orchideáinak atlaszában (MOLNÁR 2011) szerepel több, a hegység flórájára nézve új faj (E. muelleri Godfrey, E. nordeniorum Robatsch, E. voethii Robatsch). Az atlasz a korábban közölt taxonok elterjedéséről is árnyaltabb képet ad, köszönhetően a herbáriumi gyűjtések és Óvári Miklós terepi megfigyelései feldolgozásának. MoLNÁR (2011) az előfordulásokat a Közép-európai Flóratérképezés (KEF) rendszerében szerkesztett térképeken mutatta be. MolNÁR et al. (2012) dolgozatában a 2010-ig gyűjtött lapok kerültek feldolgozásra. A herbáriumi revízió során kiderült, hogy az E. voethii-t már korábban gyűjtötték a területen, Szabó István 1974-ben, Gyenesdiás területén és Galambos István 1982-ben, a Tátikán. Az E. purpurata és az E. palustris első adatait (2014) a hegységből Bauer Norbert herbáriumi példányai igazolják (BP herbárium).

A Keszthelyi-hegység területéről a fentiek alapján 10 Epipactis-fajnak volt irodalmi vagy herbáriumi adata. Munkám célja a Keszthelyi-hegység területén előforduló nőszőfűfajok adatainak megerősítése és új állományok feltérképezése volt.

\section{Anyag és módszer}

Jelen közleményben a Keszthelyi-hegység határait a Keszthelyi-hegység kiemelt jelentőségű természetmegőrzési terület (HUBF20035) határvonalával azonosítottam, elsősorban erre a 14898,12 ha-os területre koncentráltam munkám során.

Előzetes terepbejárások $(2014,2015)$ után a 2016-2017-es években került sor a terület szisztematikus bejárására. Az egyes fajok határozásához elsősorban MoLNÁR (2011) és DELFORGE (2006) művei, illetve az Arbeitskreise Heimische Orchideen bayerni csoportjának a nőszőfüfajokkal nagy részletességgel foglalkozó weboldala [1] szolgált segítségül. Köszönettel tartozom Csábi Miklósnak, Makádi Sándornak segítségükért a határozásokban, illetve Óvári Miklósnak, akivel 2014-ben volt alkalmam egy terepnapot eltölteni a hegységben, minek során több faj jellegzetességeire is felhívta figyelmemet.

A fellelt nőszőfü tövek helyzetét GPS segítségével meghatároztam, az egy pontban (közelítőleg 5 méteres körzetben) előforduló tövek számát feljegyeztem. Összesen 2799 tő nőszőfü felvételezését végeztem el a területen.

Az enumerációban az egyes herbáriumi lapokat őrző gyűjteményeket az alábbi rövidítésekkel jelzem: BP - MTM Növénytár Herbarium Carpato-Pannonicum gyűjteménye, Budapest; BTM - MTM Bakonyi Természettudományi Múzeuma, Zirc; DE - Debreceni Egyetem herbáriuma, Debrecen; SAMU - Savaria Múzeum, Szombathely.

Az egyes fajok esetében először a település, majd a pontosabb lokalitás szerepel, ahol releváns (ritkább fajok, nagyobb előfordulások), ott feltüntetésre kerül az egyedszám, majd az adat felvételekor jelen lévők nevének rövidítése és a felvétel évszáma szerepel. Szögletes zárójelben a közép-európai flóratérképezési kvadrátok azonosítója került megadásra.

Rövidítések: BJ: Bódis Judit, NT: Nagy Timea, ÓM: Óvári Miklós, PB: Pacsai Bálint, TA: Takács Attila. 


\section{Enumeráció}

Epipactis albensis Nováková \& Rydlo

Ined.: Uzsa: Boc-hegy oldalában, útszegélyben 18 tő (PB 2016) [9169.2], Istvándi-erdőben, üde nyiladék szegélyében (PB 2016) [9069.4]; Sümeg: Malom-út mentén, útszegélyben 2 tő (BJ, NT, PB \& TA 2016) [9069.4].

Epipactis atrorubens (Hoffm. ex Bernh.) Besser

Herb.: Cserszegtomaj: Gyötrős (Bauer Norbert 2007, BP) [9169.4]; Keszthely: (Hutter Mihály XIX. század, BP; Horvát Andor 1974 BTM és 1975 BTM), Tüskés (Bauer Norbert 2010, BP) [9169.4], Négyszögű-hegy (Bauer Norbert 2010, BP) [9169.4]; Gyenesdiás: (Siroki Zoltán 1955, DE); Ló-hegy (Szabó István 1974, BTM) [9269.2].

Lit:: Keszthely: (BORBÁs 1900); Gyenesdiás: Gyenes völgyeiben (BoRBÁs 1900); 9269.2 és 9169.4 kvadrátok (MolnÁR 2011); Keszthely: Négyszögű-hegy /dolomitgyep cönológiai felvételben/ (BAUER 2014) [9169.4]; Rezi: Púpos-hegy /zárt dolomitsziklagyep cönológiai felvételben/ BAUER 2014) [9169.1].

Ined.: Keszthely: Pilikáni-út mentén 1 virágzó és 7 vegetatív tő (PB 2016) [9169.4]; Cserszegtomaj: egykori okkerbányához közel, nyílt dolomitfelületen kb. 150 tő (PB 2016 -BJ megfigyelése, 2011) [9169.4]; Rezi: Pörkölt-hegyek lábánál, a közút mentén 1 virágzó tő (PB 2016) [9169.2], Bányafő-tető keleti oldalán, két ponton összesen 3 tő (BJ \& PB 2016) [9169.2].

Epipactis helleborine (L.) Crantz

Herb.: Balatonederics: Edericsi-erdő (Horvát Andor 1973, BTM); Vállus: Szék-tető (Bauer Norbert 2006, BP) [9169.4]; Várvölgy: Kisláz-hegy (Bauer Norbert 2006, BP) [9169.2]; Zalaszántó: Tátika (Piers Vilmos 1892, SAMU) [9069.4].

Lit.: Keszthely (BoRBÁs 1900); Gyenesdiás: Gyenes erdeiben (BorBÁs 1900), Pető-hegy (JAKUCS \& FEKETE in JAKUCS 1961) [9269.2], „Csidervölgy” (JAKUCS \& FEKETE in JAKUCS 1961); Balatongyörök: Apró-hegyek (JAKUCS \& FEKETE in JAKUCS 1961) [9270.1]; 9269.2, 9270.1, 9169.4, 9169.3, 9169.2, 9169.1 (1950 előtti adat), 9069.4 kvadrátok (MolNÁR 2011).

Ined.: Keszthely: Tüskés (PB 2016) [9169.4], Pénzes-gödör (PB 2015, 2016) [9169.4], Szárhegy (PB 2014, 2015, 2016) [9269.2], Pilikáni-fenyves (PB 2015, 2016) [9269.2], Tüskéstói-lap (PB 2016) [9169.4], Négyszögű-hegy (BJ \& PB 2016) [9169.4], Pilikári-erdő (PB 2015, 2016) [9169.4], Hideg-völgy (PB 2016) [9169.4], Nagy-Messzelátó-hegy (BJ \& PB 2016) [9169.4]; Gyenesdiás: Ló-hegy (PB 2016) [9269.2], Tüskés-lap (PB 2016) [9269.2], Nyilaserdő (PB 2016) [9269.2], gyenesdiási koronglövő-pályánál (PB 2014, 2016) [9269.2], Pórakháti völgy (PB 2014, 2016) [9269.2], Öreg-szék-tető (PB 2014, 2015, 2016) [9169.4], Kőfejtő (PB 2016) [9169.4], Szék-tető (PB 2014, 2016) [9169.4]; Vonyarcvashegy: Hosszú-völgy (PB 2014, 2015, 2016) [9269.2], Malacos-tetőn (PB 2016) [9269.2]; Balatongyörök: Pad-kői erdő (PB 2015, 2016) [9169.4], Kígyós-völgy (PB 2014, 2015, 2016) [9170.3], Boncsos-tető (PB 2016) [9170.3], Keserü-berek (PB 2015, 2016) [9170.3], Hajagos (PB 2016) [9270.1], dolomitbánya (BJ 2016) [9270.1]; Nemesvita: Cseres-erdő (PB 2016) [9169.4], Ördög-ágya (PB 2014, 2016) [9169.4]; Vállus: Rózsa-mező (PB 2014, 2015) [9169.4], Pórag-hát (PB 2014, 2016) [9169.4], Sátor magasa (PB 2016) [9169.4], Csalános-árok (PB 2016) [9169.4], Takács-út (PB 2016) [9169.4], Nyugodó-hegy (PB 2015, 2016) [9169.4], Vállusi-erdő (PB 2015, 2016) [9169.4], Iván-hát (PB 2015, 2016) [9169.4], Hűs-lap (PB 2016) [9169.4], Büdöskúti-erdő (PB 2014, 2015, 2016) [9169.4], Büdöskúti arborétum (PB 2014, 2015, 2016) [9169.4], Köves-tető (PB 2016) [9169.4], Szapu-völgy (PB 2014, 2016) [9169.4], Szent Miklós-forrásnál (PB 2015, 2016) [9169.4], Barbacsi-erdő (PB 2014, 2015) [9169.4], Cseresznyés-völgy (PB 2016) [9169.4]; Várvölgy: Szebike-erdőben 331 tő (PB 2016) [9069.4], Rókalyuki-erdő (PB 2014, 2016) [9069.4], Borgáta (PB 2014, 2016) [9069.4], Tinóállás (PB 2016) [9069.4], Puszta-mezői szőlőhegy (PB 2014, 2015, 2016) [9069.4], 
Berkenyés (BJ \& PB 2016) [9169.2], Ördög-köveknél (BJ \& PB 2016) [9169.2], Itató-árok (BJ \& PB 2016) [9169.2]; Rezi: Fagyoskereszt (PB 2016) [9169.4], Szentmiklósi-völgy (PB 2016) [9169.4], Pörkölt-hegyek (PB 2016) [9169.4], Csorna-kúti völgy (PB 2015, 2016) [9169.3], Csorna-kút-tető (PB 2016) [9169.4], Keserú-torony (PB 2014, 2016) [9169.3], Bányafő-tető (PB 2016) [9169.4], Púpos-hegy (PB 2016) [9169.1]; Uzsa: Boc-hegy (PB 2016) [9169.2], Ferenc-ház (PB 2016) [9169.2]; Zalaszántó: Vátkai-rét-dűlő (BJ \& PB 2016) [9169.2], Hermán-tó-hegy (NT \& TA 2016) [9069.3], Farkas-hegy (NT, PB \& TA 2016) [9069.4], Tátika (PB 2014, 2015, 2016) [9069.4], Gombás-erdő (PB 2014, 2016) [9069.4], Szebike-völgy (PB 2014, 2015, 2016) [9069.4]; Sümegprága: Fekete-kapu (PB 2016) [9069.4], Csernely-domb (PB 2016) [9069.4].

\section{Epipactis leptochila Godfery}

Herb.: Uzsa: Kis-Láz-tető (Bauer Norbert 2006, BP) [9169.2].

Lit.: Nemesvita: Cseres-tető (Takács Géza ap. Molnár 1998) [9170.3]; 9169.4 és 9170.3 kvadrátok (MolnáR 2011).

Ined.: Balatongyörök: Kígyós-völgy (PB 2016) [9170.3]; Vállus: Büdöskúti arborétum (PB 2014, 2015, 2016) [9169.4], Görbe-tető (РB 2016) [9169.4]; Várvölgy: Borgáta (PB 2014, 2016) [9069.4]; Rezi: Fagyoskereszt (PB 2016) [9169.4]; Uzsa: Boc-hegy (PB 2016) [9169.2], Ferenc-ház (PB 2016) [9169.2], Istvándi-erdő (PB 2016) [9069.4], Itató-árok (BJ \& PB 2016) [9169.2]; Zalaszántó: Farkas-hegy (PB 2016) [9069.4]; Sümegprága: Csernely-domb (PB 2016) [9069.4].

Epipactis microphylla (Ehrh.) Sw.

Herb.: Keszthely: Büdöskúti-völgy (Vajda László 1935, BP); Vállus: Büdöskút (Galambos István 1980, BTM), Görbe-tető (Galambos István 1980, BTM) [9169.4], Büdöskúti-erdő (Bauer Norbert 2012, BP) [9169.4]; Rezi: Rezi-várhegy (Papp József 1953, BP) [9169.1], „Rezi” (Horvát Andor 1974, BTM).

Lit.: 9269.2, 9170.3, 9169.1 (1990 előtti adat) és 9169.4 kvadrátok (MoLNÁR 2011).

Ined.: Keszthely: Nagy-mező (PB 2015) [9169.4], Pilikári-erdő (PB 2015, 2016) [9169.4], Pénzesgödör (PB 2015, 2016) [9169.4], Tüskés (PB 2014, 2015, 2016) [9169.4]; Gyenesdiás: Ló-hegy (PB 2016) [9169.4]; Vonyarcvashegy: Hosszú-völgy (PB 2015, 2016) [9169.4], Malacos-tető (PB 2016) [9169.4]; Balatongyörök: Bélap-völgy (PB 2015) [9270.1], Kerékhegy (BJ, NT \& TA 2016) [9270.1], Pad-kői erdő (PB 2014, 2015, 2016) [9169.4], Boncsostető (PB 2016) [9170.3], Fekete-hegy (PB 2015) [9170.3], Kígyós-völgy (PB 2015, 2016) [9170.3], Sárkány-erdő (PB 2016) [9170.3]; Balatonederics: Sipostorok (PB 2015, 2016) [9170.3]; Nemesvita: Cseres-erdő (PB 2014, 2016) [9170.3], Vékony-cser (PB 2016) [9170.3]; Lesencefalu: Ördög-árok (PB 2014, 2016) [9170.3], Hajag-tető (PB 2016) [9169.4], Somos-tető (PB 2015, 2016) [9169.4]; Vállus: Szapu-völgy (PB 2014, 2015, 2016) [9169.4], Szent Miklós-forrás mellett (PB 2015, 2016) [9169.4], Görbe-tető (PB 2015, 2016) [9169.4], Büdöskúti-erdő (PB 2015) [9169.4], Szent Miklós-völgy (PB 2015, 2016) [9169.4], Büdöskúti arborétum (PB 2014, 2015, 2016) [9169.4], Sárostói-út (PB 2015) [9169.4], Kisfenyves (PB 2015, 2016) [9169.4]; Rezi: Pörkölt-hegyek (PB 2016) [9169.4]; Uzsa: Ferencház (PB 2015, 2016) [9169.2], Körtefás-rét (PB 2016) [9069.4]; Zalaszántó: Gombás-erdő (PB 2016) [9169.2].

Epipactis moravica Batousek

Lit.: 9169.4-es kvadrát (Óvári Miklós ap. MolNÁR 2011).

Ined.: Vállus: Vállusi-erdő (PB 2016) [9169.4].

Epipactis muelleri Godfery

Lit.: 9169.4 és 9170.3 kvadrátok (MoLNÁR 2011).

Ined.: Vonyarcvashegy: Vonyarci-fenyves (PB 2016) [9269.2]; Gyenesdiás: Ló-hegy (PB 2016) [9269.2], Tüskés-lapon, út mentén 22 tő (PB 2015, 2016) [9269.2], Nyilas-erdő (PB 2014) [9269.2]. 


\section{Epipactis neglecta Kümpel}

Ined.: Gyenesdiás: Ló-hegy (PB 2016) [9269.2]; Balatongyörök: Kígyós-völgy (PB 2015, 2016) [9269.2], Pad-kői erdő (PB 2016) [9169.4], Keserű-berek (PB 2016) [9270.1], Sárkány-erdő (PB 2016) [9270.1]; Vállus: Büdöskúti arborétum (PB 2015, 2016) [9169.4], Köves-tető (PB 2016) [9169.4], Szapu-völgy (PB 2016) [9169.4], Büdöskúti-erdő (PB 2016) [9169.4], Cseresznyés-völgy (PB 2016) [9169.4]; Lesencefalu: Ördög-árok (PB 2016) [9270.1], Csertető (PB 2016) [9270.1], Nyivány (PB 2016) [9270.1]; Rezi: Kis-cser-völgy (PB 2016) [9169.1].

\section{Epipactis nordeniorum Robatsch}

Herb: Várvölgy: Kisláz-hegy (Bauer Norbert 2004, BP) [9169.2].

Lit:: 9169.2 és 9069.4 kvadrátok (MoLNÁR 2011).

Ined.: Várvölgy: Rókalik-erdő (PB 2016) [9169.2], Régi erdészház közelében (PB 2014, 2016) [9069.4], Tűzkő-hegy (PB 2016) [9069.4]; Uzsa: Ferenc-ház (PB 2014, 2015, 2016) [9169.2 és 9069.4], Boc-hegy (PB 2014, 2015, 2016) [9169.2], Uzsai-erdő (PB 2014, 2016) [9069.4], Istvándi-erdő (PB 2016) [9069.4]; Zalaszántó: Szebike-erdő (PB 2014, 2016) [9069.4], Szebike-völgy (PB 2014, 2016) [9069.4], Bárány-legelő (BJ, NT, PB \& TA 2016) [9069.4]; Bazsi: Delelő-kút közelében (PB \& TA 2016) [9069.4].

Epipactis palustris (L.) Crantz

Herb.: Balatongyörök: Csereze-hegy, murvabánya (Bauer Norbert 2014, BP) [9270.1].

Lit.: Keszthely (BORBÁs 1900); Vonyarcvashegy: vasúti árokban (ALMÁDI 1998) [9269.2] - ezek az adatok a Keszthelyi-riviéra területéhez, nem a Keszthelyi-hegységhez sorolhatók.

Ined.: Balatongyörök: a felhagyott Csereze-hegyi dolomitbánya területén 24 tő (BJ 2016) [9270.1].

Epipactis peitzii H.Neumann \& Wucherpf.

Ined.: Vonyarcvashegy: Hosszú-völgy (PB 2014) [9269.2]; Balatongyörök: Sárkány-erdőben 59 tő (PB 2015, 2016) [9170.3], Keserű-berek (ÓM \& PB 2014, PB 2015, 2016) [9170.3], Padkő (ÓM \& PB 2014, PB 2015, 2016) [9170.3], Hosszú-völgy (PB 2015, 2016) [9170.3]; Nemesvita: Vékony-cser (PB 2016) [9170.3]; Lesencefalu: Mész-völgy (PB 2016) [9170.3]; Rezi: Pörkölt-hegyek (PB 2016) [9169.1], Púpos-hegy (PB 2016) [9169.1].

Epipactis pontica Taubenheim Ined.: Sümeg: Szebike-erdőben, út mentén, két foltban, összesen 30 tő (PB 2016) [9069.4].

Epipactis purpurata $\mathrm{Sm}$.

Herb.: Lesenceistvánd: Nagy Láz-tető (Bauer Norbert 2014, BP) [9169.2].

Lit:: Keszthelyi-hegység (MolnáR 1995).

Ined.: Uzsa: Boc-hegy oldalában. A területről Für Ágnes már 2014-ben jelezte a fajt, de az általa talált tő a bazaltbánya és Uzsa közti forgalomnak erősen kitett helyen nőtt, s ennek következtében 2015-ben valószínúleg elpusztult, 2016-ban az eredeti helytől nem messze, az úttól kissé távolabb, bükkös alatt előkerült 2 terméses töve (PB 2016) [9169.2].

Epipactis tallosii Molnár \& Robatsch

Ined.: Uzsa: Boc-hegy aljában, patak mentén (PB 2014, 2016) [9169.2], Puszta-mezői szőlőhegy (PB 2014, 2016) [9169.2]; Zalaszántó: Szebike-völgy (PB 2014, 2016) [9069.4].

Epipactis voethii Robatsch

Herb.: Zalaszántó: Tátika (Galambos István 1982, BTM, det.: Molnár V. Attila) [9069.4]; Gyenesdiás: Ló-hegy (Szabó István 1974, BTM, det.: Molnár V. Attila) [9169.4].

Lit.: 9169.4, 9069.4 (1950 előtti adat), 9170.3 kvadrátok (MoLnÁR 2011).

Ined.: Keszthely: Csorna-kúti völgyben nagy állomány (PB 2016) [9169.3]; Gyenesdiás: Petőhegy (PB 2015, 2016) [9269.2], Meszes-hegy (BJ, NT, PB \& TA 2016) [9269.2]; Vonyarcvashegy: Hosszú-völgy (PB 2016) [9269.2], Fekete-hegy (PB 2016) [9269.2], Vonyarci-cser (PB 2016) [9269.2]; Balatongyörök: Bélap-völgy (PB 2016) [9270.1], Püspökházi-völgy (PB 2016) [9170.3], Kígyós-völgy (PB 2014, 2015, 2016) [9170.3], 
Büdöskúti arborétum (PB 2014, 2015, 2016) [9170.3]; Vállus: Köves-tető (PB 2015, 2016) [9169.4], Büdöskút (PB 2015, 2016) [9169.4], Görbe-tető (PB 2016) [9169.4], Vállusi-erdő (PB 2015, 2016) [9169.4], Hûs-lap (2016) [9169.4], Sárostói-út (PB 2015, 2016) [9169.4], Kis-Messzelátó-hegy (PB 2015) [9169.4], Büdöskúti-erdő (PB 2016) [9169.4], Kis-fenyves (PB 2015) [9169.4], Iván-hát (PB 2014, 2016) [9169.4], Nyugodó-hegy (PB 2016) [9169.4], Várad-tető (PB 2015, 2016) [9169.4], Cseresznyés-árok (PB 2016) [9169.4], Borzas-lapos (PB 2016) [9169.4], Barbacsi-erdő (PB 2015) [9169.4], Szapu-völgy (ÓM \& PB 2014, PB 2015, 2016), Szent Miklós-forrásnál (ÓM \& PB 2014, PB 2015, 2016); Nemesvita: Csereserdő (PB 2015) [9170.3]; Várvölgy: Rókalyuki-erdő (BJ, NT, PB \& TA 2016) [9069.4], Ördögköveknél (BJ \& PB 2016) [9169.2], Fertős-hegy (BJ \& PB 2016) [9169.2]; Rezi: Fagyoskereszt (PB 2016) [9169.4], Szentmiklósi-völgy (PB 2016) [9169.4], Keserű-torony (PB 2016) [9169.3]; Uzsa: Boc-hegy (PB 2016) [9169.2], Ferenc-ház (PB 2016) [9169.2], Istvándi-erdő (PB 2016) [9069.4], Uzsai-erdő (PB 2016) [9069.4]; Zalaszántó: Szebike-erdő (PB 2016) [9069.4], Szebike-völgy (PB 2014, 2016) [9069.4].

Epipactis $\times$ reinekei M. Bayer (E. helleborine $\times$ E. muelleri)

Ined.: Gyenesdiás: Tüskés-lapon, az Epipactis muelleri nagyobb állományában 3 tő (PB 2016) [9269.2].

\section{Az eredmények értékelése}

A Keszthelyi-hegység átfogó bejárása során több mint kétezer tő nőszőfü került elő, melyek 15 fajhoz tartoztak. A területről eddig ismert 10 faj mindegyikének sikerült jelenlétét sok esetben számos előfordulással megerősíteni. Előkerült további öt faj (E. albensis, E. neglecta, E. peitzii, E. pontica, E. tallosii), illetve egy hibrid (Epipactis $\times$ reinekei).

Különösen értékes az E. peitzii-nek a területen talált számos kisebb és néhány erősebb állománya, hiszen ezek a faj nagyobb léptékben vett negyedik ismert előfordulását jelentik a németországi locus classicus, Hohlenfels környéke (NEuMANN \& WUCHERPFENNIG 1997) és a közelmúltban közölt Budai-hegység és Pilis területe (SomLYAY et al. 2016) után. Kiemelést érdemel továbbá a Dunántúlon meglehetősen ritka E. albensis három kisebb előfordulása, illetve az E. neglecta számos állománya. A területről újonnan előkerült fajok magas száma magyarázható egyes taxonok viszonylag újkeletű elkülönítésével (E. peitzii: NEumANN \& WUCHERPFENNIG 1996, E. neglecta: KÜMPEL 1996, E. tallosii: MolNÁR \& RoBATSCH 1996), azok észrevételének, határozásának nehézségeivel (E. tallosii, E. neglecta), illetve sok esetben a területen előforduló tövek alacsony számával, ill. a fajok ritkaságával (E. albensis, E. palustris, E. pontica, E. purpurata, E. tallosii).

\section{Köszönetnyilvánítás}

Köszönöm Molnár V. Attilának, hogy a magyarországi orchidea-adatbázis Zala megyei Epipactis-okat tartalmazó lapjait rendelkezésemre bocsátotta. Hálás vagyok a közös terepbejárásokért és szakmai útmutatásokért Bódis Juditnak, Nagy Timeának, Óvári Miklósnak és Takács Attilának, illetve Für Ágnesnek a térképezésben nyújtott segítségéért, Bauer Norbertnek a BP-herbárium átnézése során nyújtott segítségéért.

Munkámat az Emberi Erőforrások Minisztériuma ÚNKP-17-1 kódszámú Új Nemzeti Kiválóság Programja támogatta. 


\section{Irodalom}

ALMÁDI L. (1998): Néhány aktuális adat a Balaton-felvidék florisztikai ismeretéhez - Kitaibelia 3 (2): 253254.

BAUER N. (2014): A Bakony-vidék szárazgyepjei - Sztyeprétek és sziklagyepek osztályozása és növényföldrajzi karaktere (Dry grasslands of the Bakony Region - Classification and phytogeographical character of dry and rocky grasslands). - Magyar Természettudományi Múzeum, Budapest. A Bakony természettudományi kutatásának eredményei 33.

BoDNÁR B. (1957): Adatok Wierzbicki Péter keszthelyi működéséhez - Agrártörténeti Szemle 1 (1-2): 57-67.

Borbás V. (1900): A Balaton tavának és partmellékének növényföldrajza és edényes növényzete. A Balaton tudományos Tanulmányozásának Eredményei II. - Hornyánszky Viktor csász. és kir. udvari könyvnyomdája, Budapest.

DELFORGE P. (2006): Orchids of Europe, North Africa and the Middle East. - A\&C Black Publishers Ltd., London.

JAKUCS P. (1961): Die phytozönologischen Verhältnisse der Flaumeichen-Buschwälder Südostmitteleuropas. - Akadémiai Kiadó, Budapest.

KüMPEL H. (1996): Die wildwachsenden Orchideen der Rhön. Lebensweise, Verbreitung, Gefährdung, Schutz. - Gustav Fischer Verlag, Jena.

FEKETE G. (1964): A Bakony növénytakarója. - A Bakony természettudományi kutatásának eredményei 1: 9-53.

MolNÁR V. A., SULYOK J. \& VIDÉKI R. (1995): Vadon élő orchideák. - Kossuth könyvkiadó, Budapest.

Molnár V. A. \& Robatsch K. (1997): Epipactis tallosii A. Molnár \& K. Robatsch spec. nov., eine neue Epipactis-Art aus Ungarn. - Journals Europäischer Orchideen 28 (4): 787-794.

MolNÁR V. A., VIDÉKI R. \& VLČKO J. (1998): Adatok hazai Epipactis-fajok ismeretéhez II. - Kitaibelia 3 (2): 287-289.

MolNÁR V. A. (szerk.) (2011): Magyarország orchideáinak atlasza. - Kossuth kiadó, Budapest.

Molnár V. A., TakÁcs A., Horváth O., Vojtkó A., Király G., Sonkoly J., Sulyok J. \& SRamkó G. (2012): Herbarium database of hungarian orchids I. Methodology, dataset, historical aspects and taxa. Biologia 67 (1): 79-86.

NEUMANn H. \& WuCHERPFENNIG W. (1997): Epipactis peitzii H.Neumann \& Wucherpfennig spec. nov., eine neue Orchideenart aus Deutschland. - Journals Europäischer Orchideen 28 (4): 787-794.

SOMLYAY L., MAKÁDI S. \& CSÁBI M. (2016): Adatok Budapest környéke flórájának ismeretéhez II. - Kitaibelia 21 (1): 33-50.

SzABó I. (1987): A Keszthelyi-hegység növényvilágának kutatása. - A Bakonyi Természettudományi múzeum Közleményei 6: 77-98.

SzODFRIDT I. (1960): Új adatok a Keszthelyi-hegység és a Dél-Bakony flórájához. - Botanikai Közlemények 48: 75-76.

\section{Hivatkozott világháló oldalak:}

[1] http://www.aho-bayern.de/epipactis/fs_epipactis_1.html (Hozzáférés: 2018.05.21.)

Beérkezett / received: 2017. 03.14. • Elfogadva / accepted: 2018. 05. 26. 
PACSAI B. (2018):

Adatok a Keszthelyi-hegység nőszőfüfajainak (Epipactis spp.) ismeretéhez / Contribution to the distribution of Epipactis species in the Keszthely Mts

Kitaibelia 23 (1): 8-14.

DOI: 10.17542/kit.23.8

\section{Elektronikus melléklet / Electronic appendix}

A közleményben szereplő fajok habitus- és közeli virágfotói, valamint előfordulásaik a vizsgált területen / Habit and close-up photographs, and distribution maps of the enumerated taxa on the study area

Közölt adatok / Enumerated data (ined.)

$\bigcirc$ Korábban publikált vagy herbáriumi példánnyal dokumentált adatok / Data previously published or vouchered by herbarium specimens

Epipactis albensis Nováková \& Rydlo

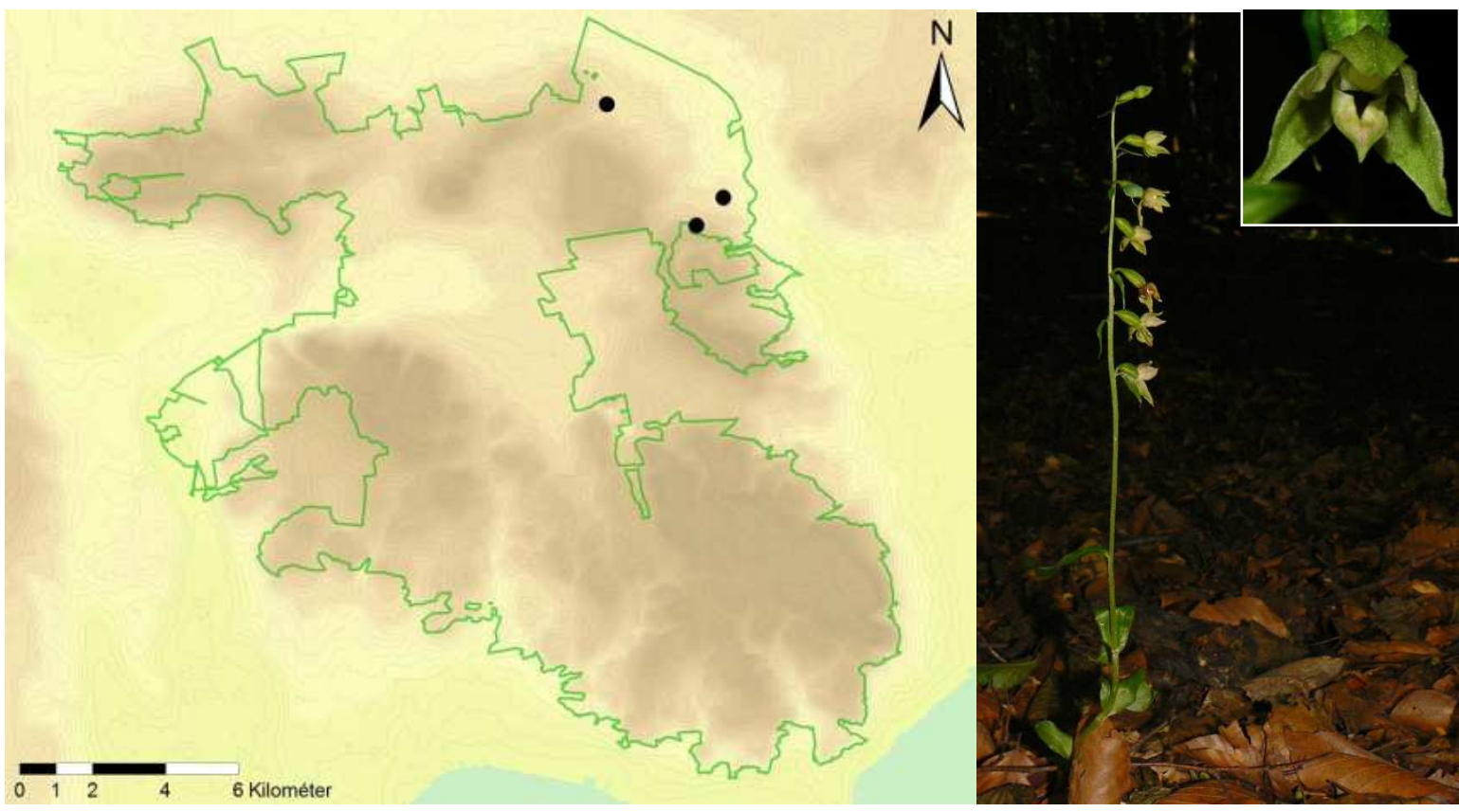

Habitus / Habit: Uzsa: Boc-hegy, 2016.08.01. Virág / Flower: Uzsa: Boc-hegy, 2016.08.01. 
Epipactis atrorubens (Hoffm. ex Bernh.) Besser

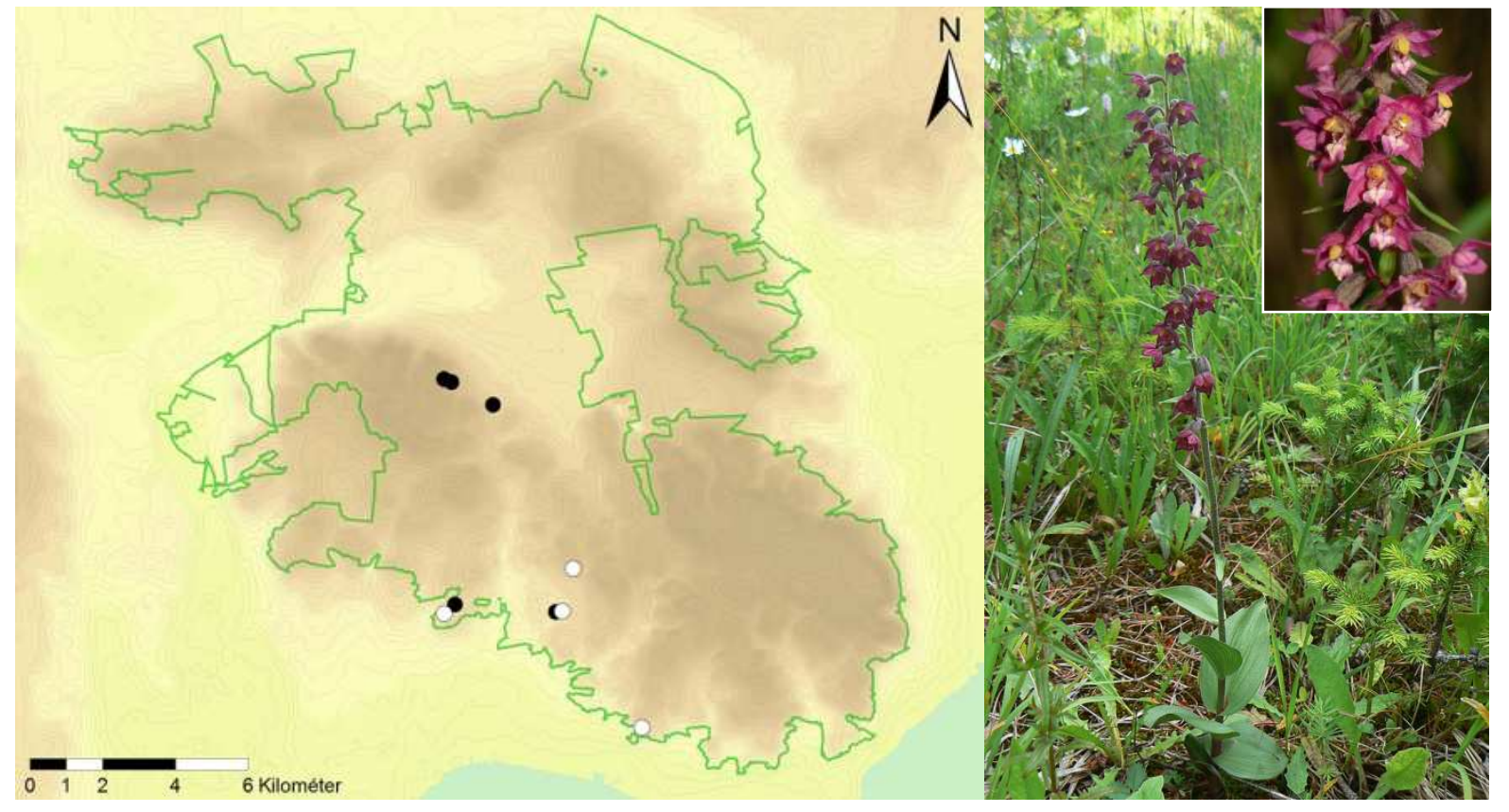

Habitus / Habit: Prein an der Rax: Bärenriegel, 2017.07.08.

Virág / Flower: Rezi: Pörkölt-hegyek, 2016.06.10.

\section{Epipactis helleborine (L.) Crantz}

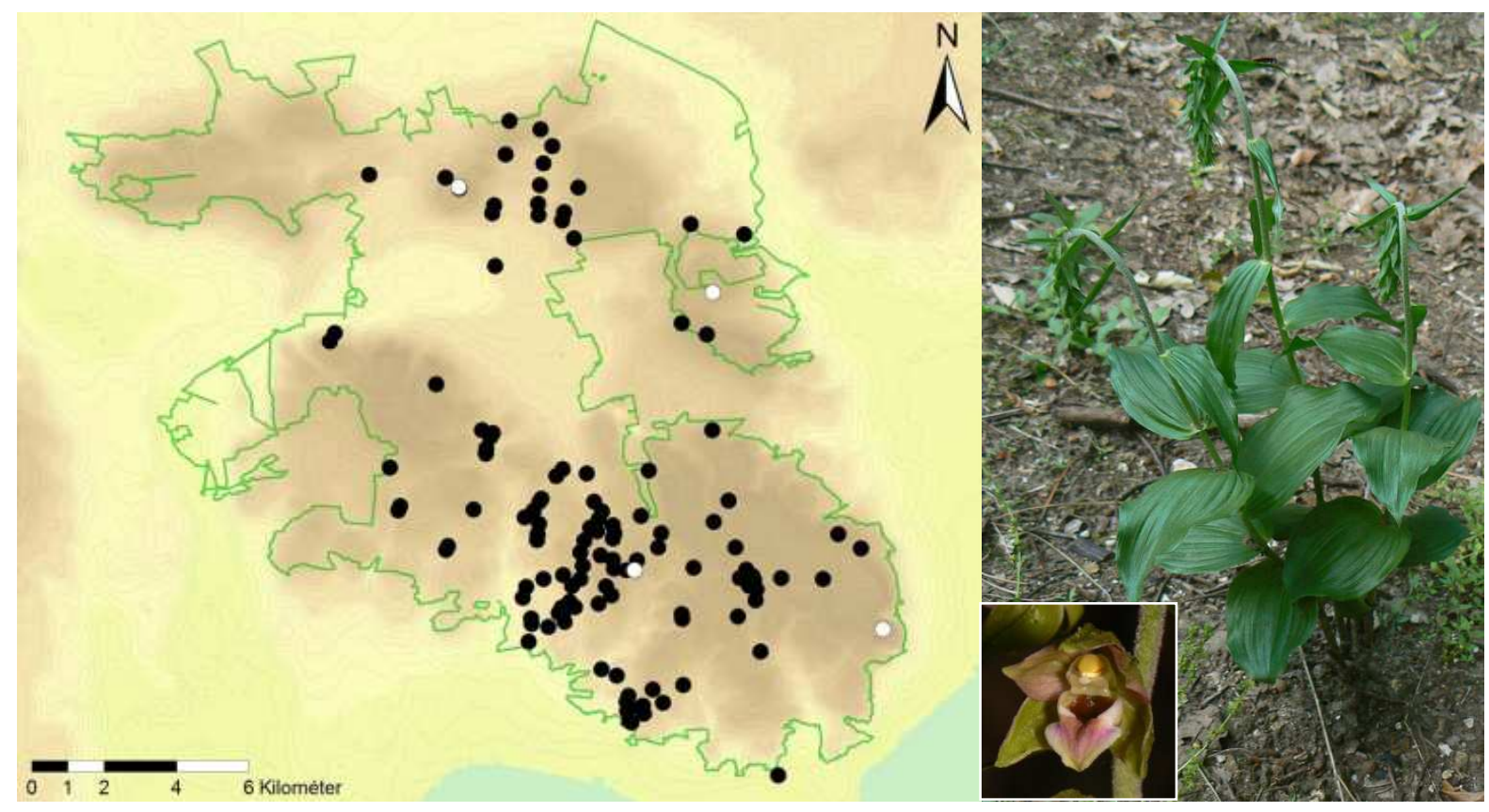

Habitus / Habit: Gyenesdiás: Pénzesgödör, 2015.06.11. Virág / Flower: Gyenesdiás: Szék-tető, 2016.06.29. 


\section{Epipactis leptochila Godfery}

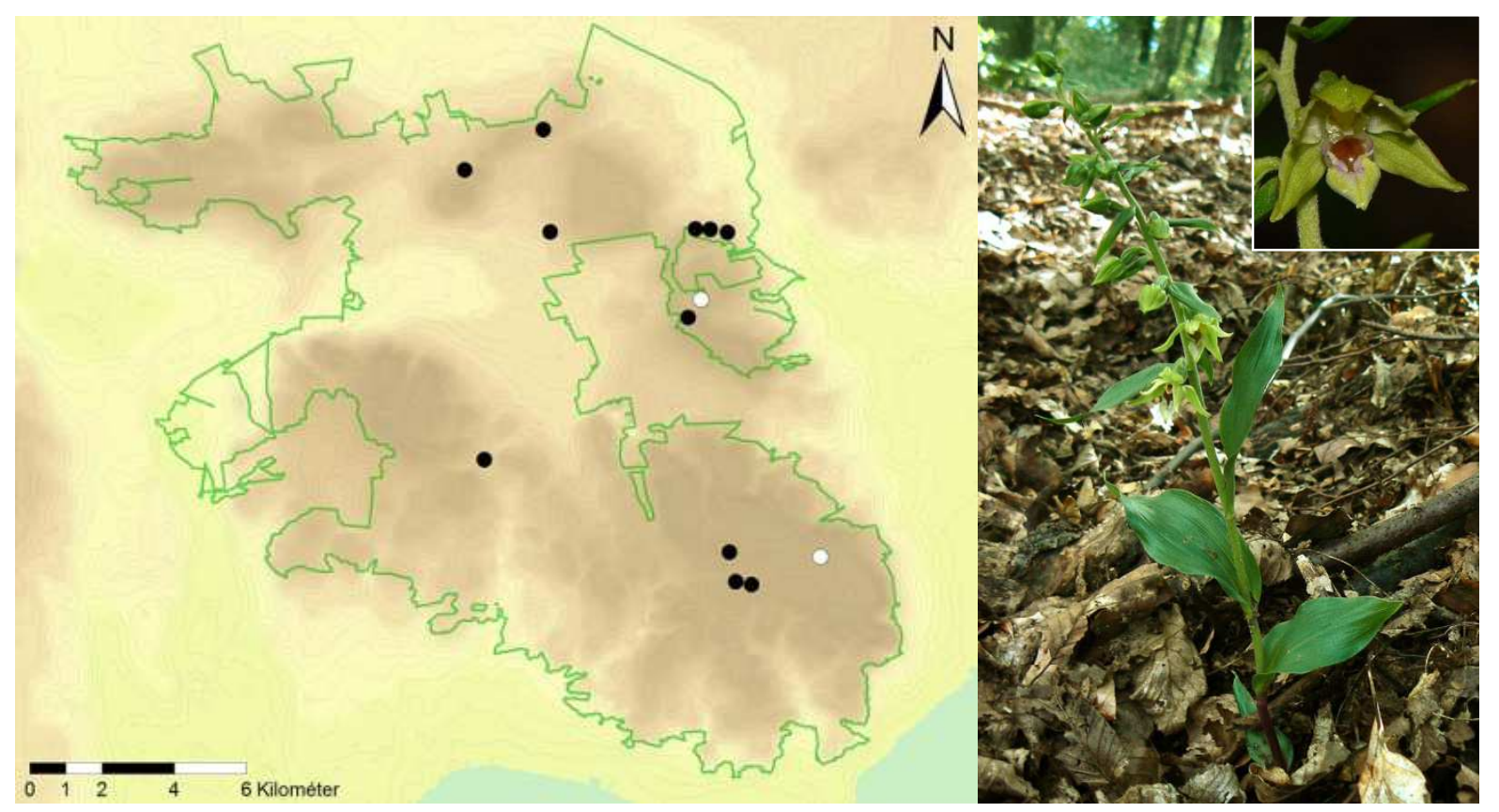

Habitus / Habit: Uzsa: Boc-hegy, 2016.08.01. Virág / Flower: Vállus: Büdöskúti-arborétum, 2015.07.15.

Epipactis microphylla (Ehrh.) Sw.

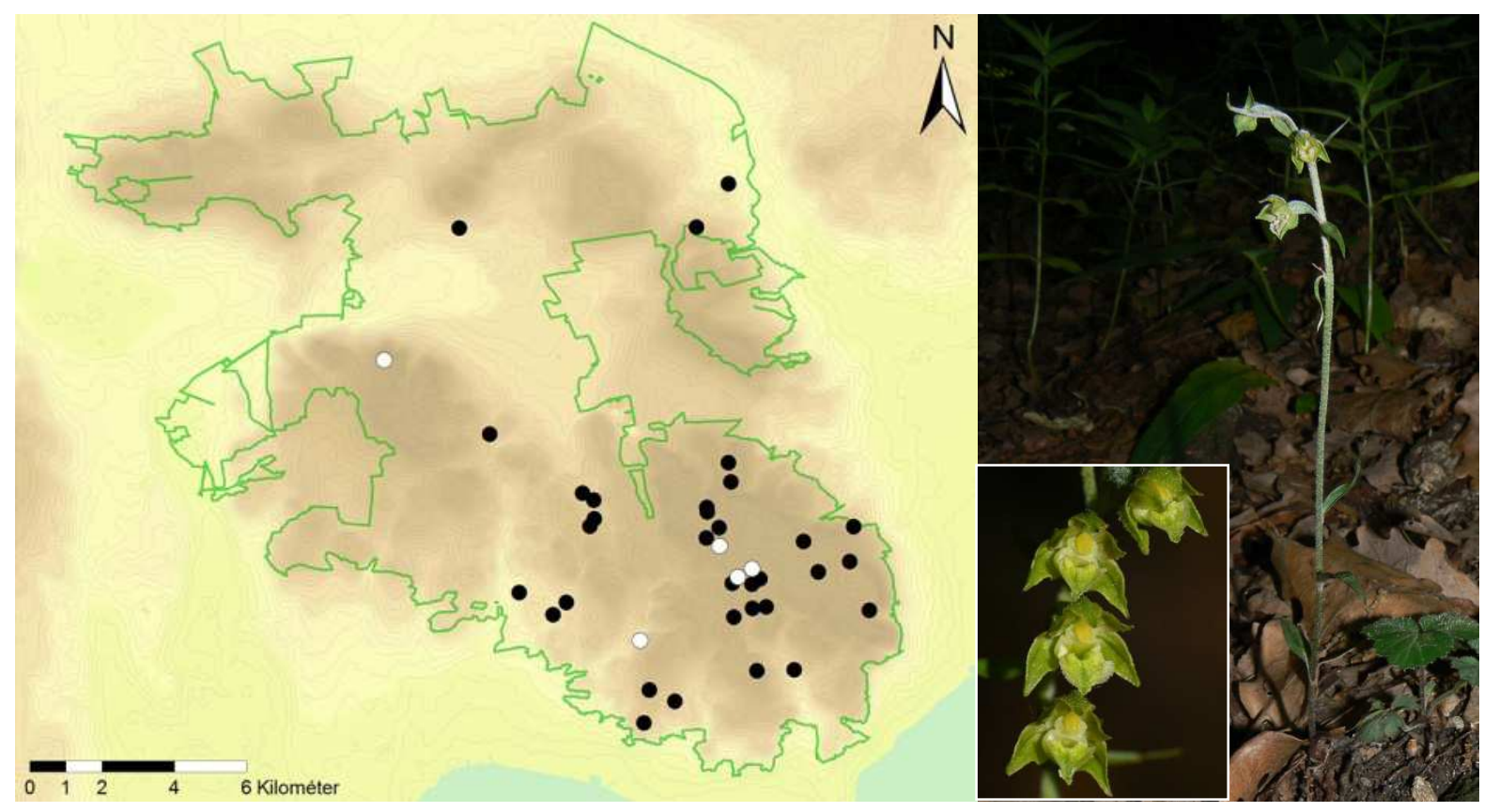

Habitus / Habit: Nemesvita: Vékony-cser, 2017.06.03. Virág / Flower: Vállus: Szent Miklós-völgy, 2016.06.18. 


\section{Epipactis moravica Batousek}

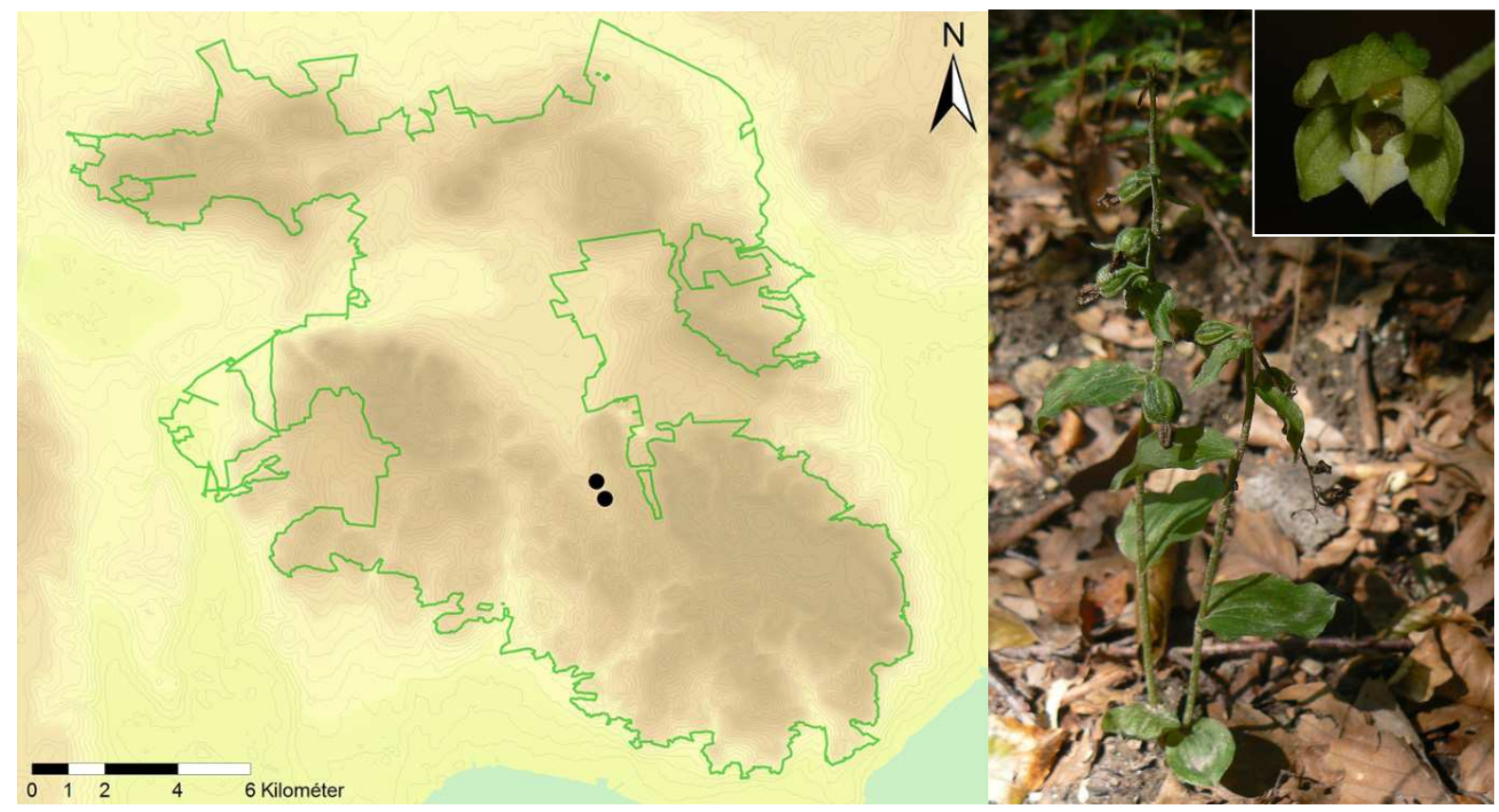

Habitus / Habit: Vállus: Vállusi-erdő, 2016.09.03.

Virág / Flower: Vállus: Vállusi-erdő, 2016.08.08.

\section{Epipactis muelleri Godfery}

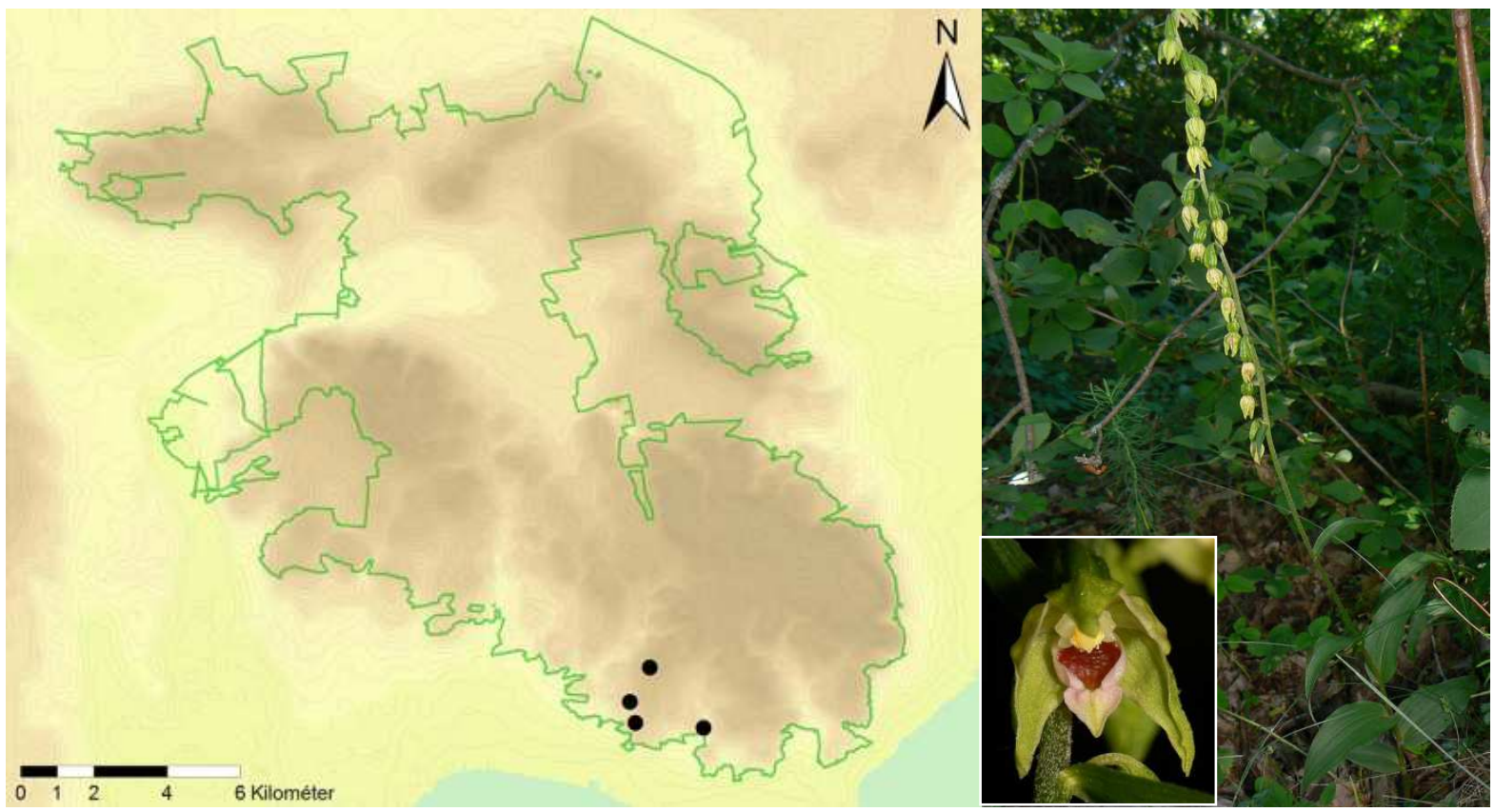

Habitus / Habit: Gyenesdiás: Tüskés-lap, 2015.06.23.

Virág / Flower: Gyenesdiás: Tüskés-lap, 2016.06.29. 


\section{Epipactis neglecta Kümpel}

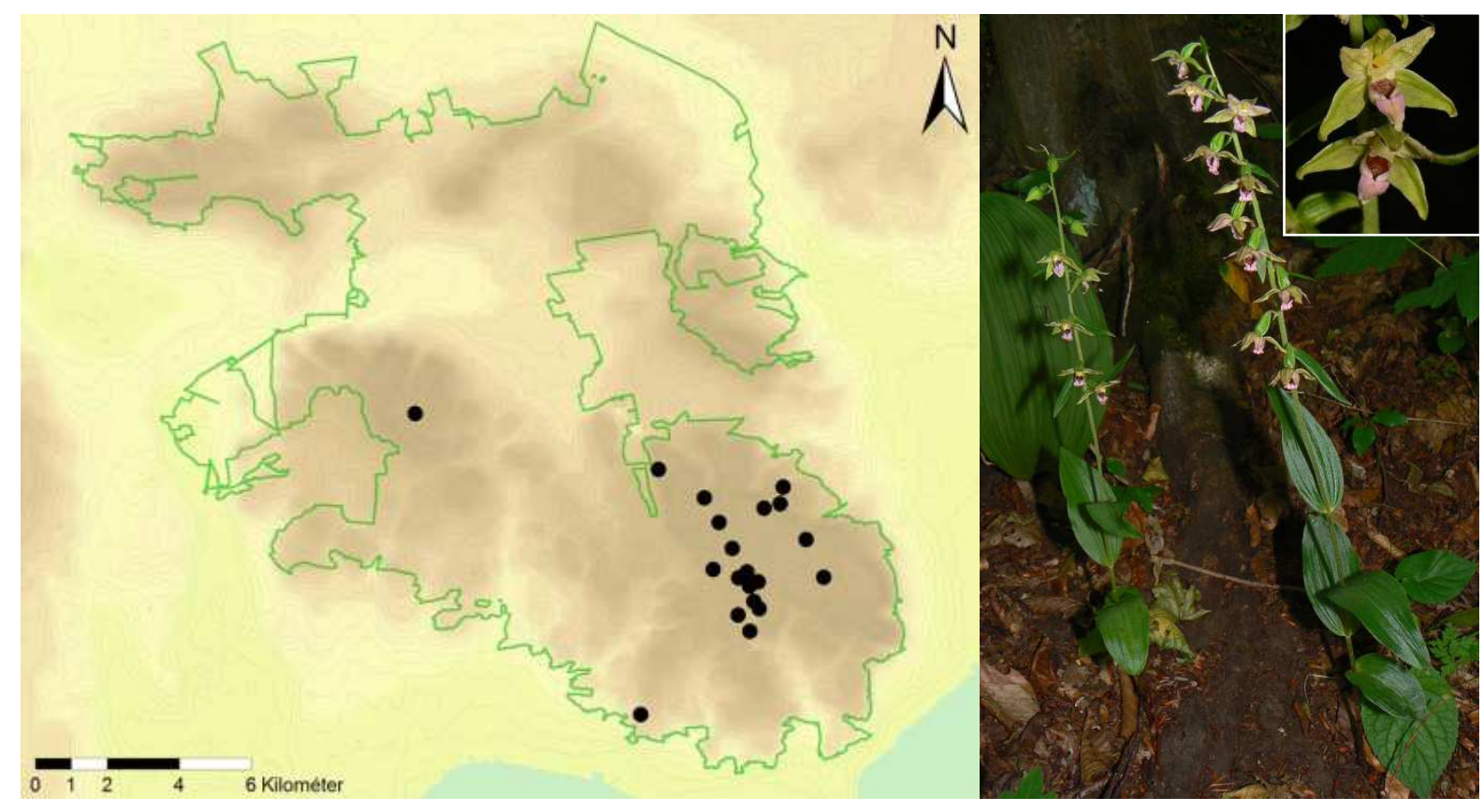

Habitus / Habit: Vállus: Büdöskúti arborétum, 2015.07.15. Virág / Flower: Vállus: Szapu-völgy, 2016.07.01.

\section{Epipactis nordeniorum Robatsch}

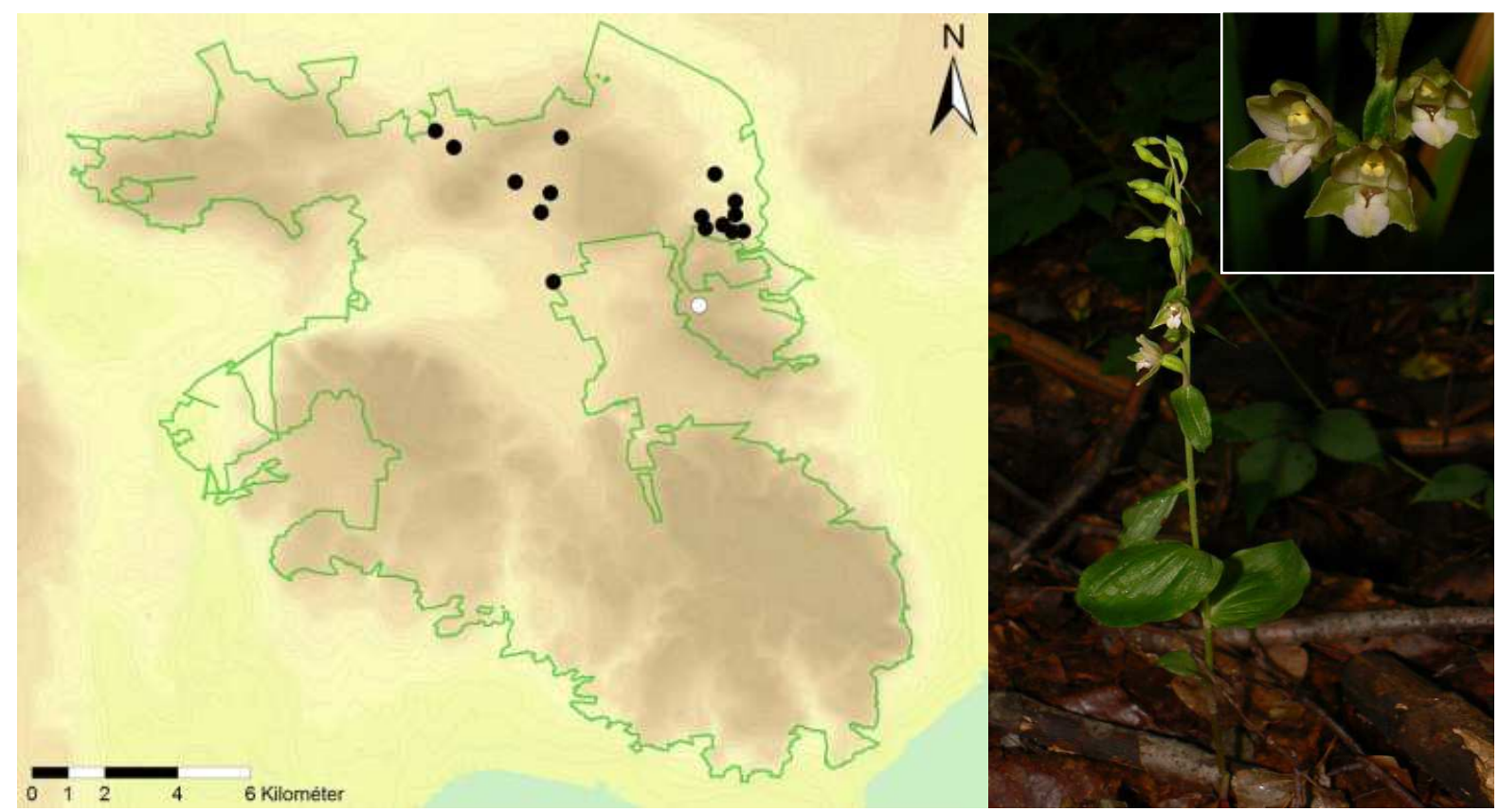

Habitus / Habit: Uzsa: Uzsai-erdő, 2016.07.29. Virág / Flower: Uzsa: Uzsai-erdő, 2016.07.29. 
Epipactis palustris (L.) Crantz

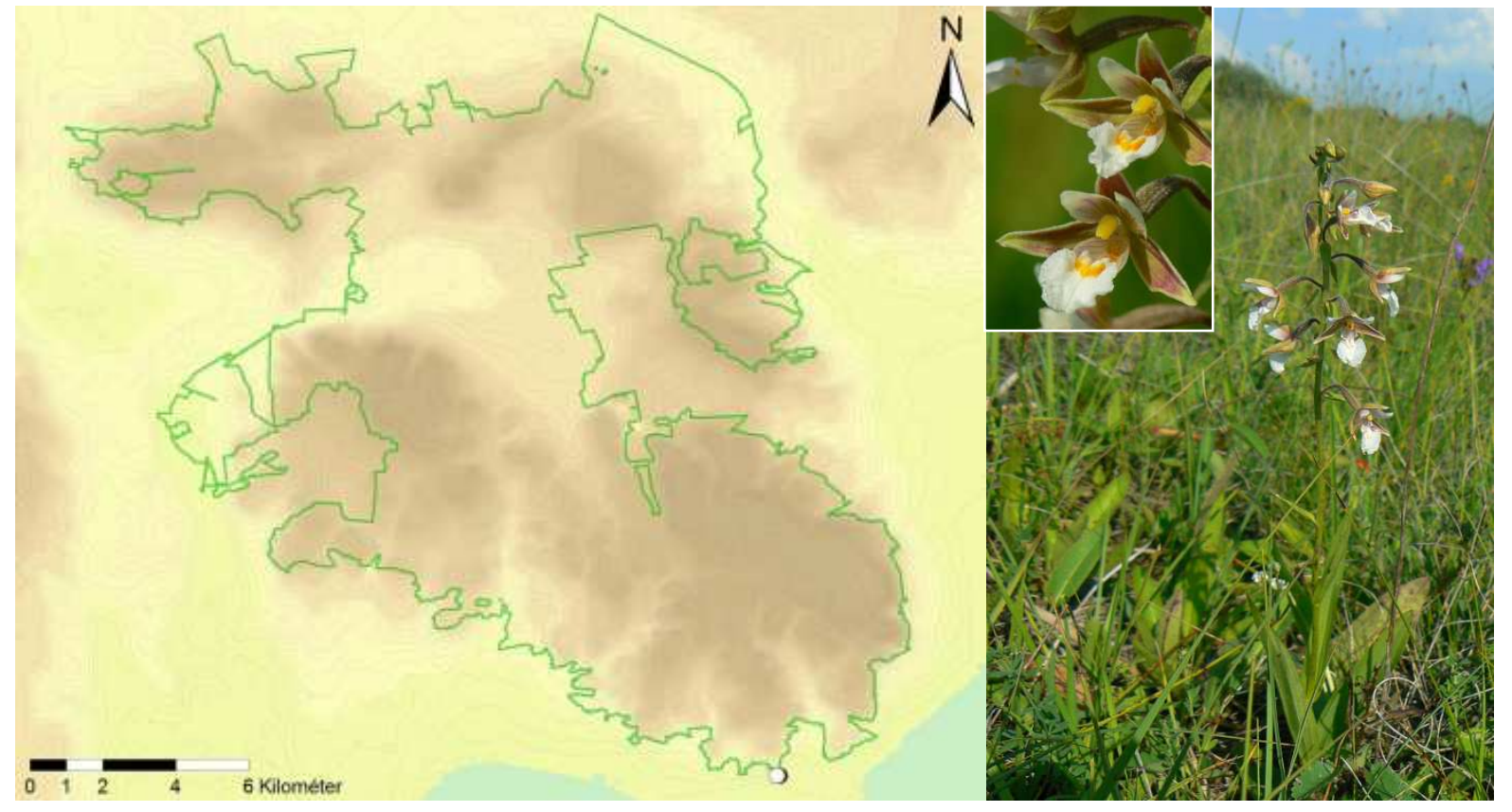

Habitus / Habit: Tapolca: Billege-mellék, 2016.06.24.

Virág / Flower: Tapolca: Billege-mellék, 2016.06.24.

Epipactis peitzii H.Neumann \& Wucherpf.

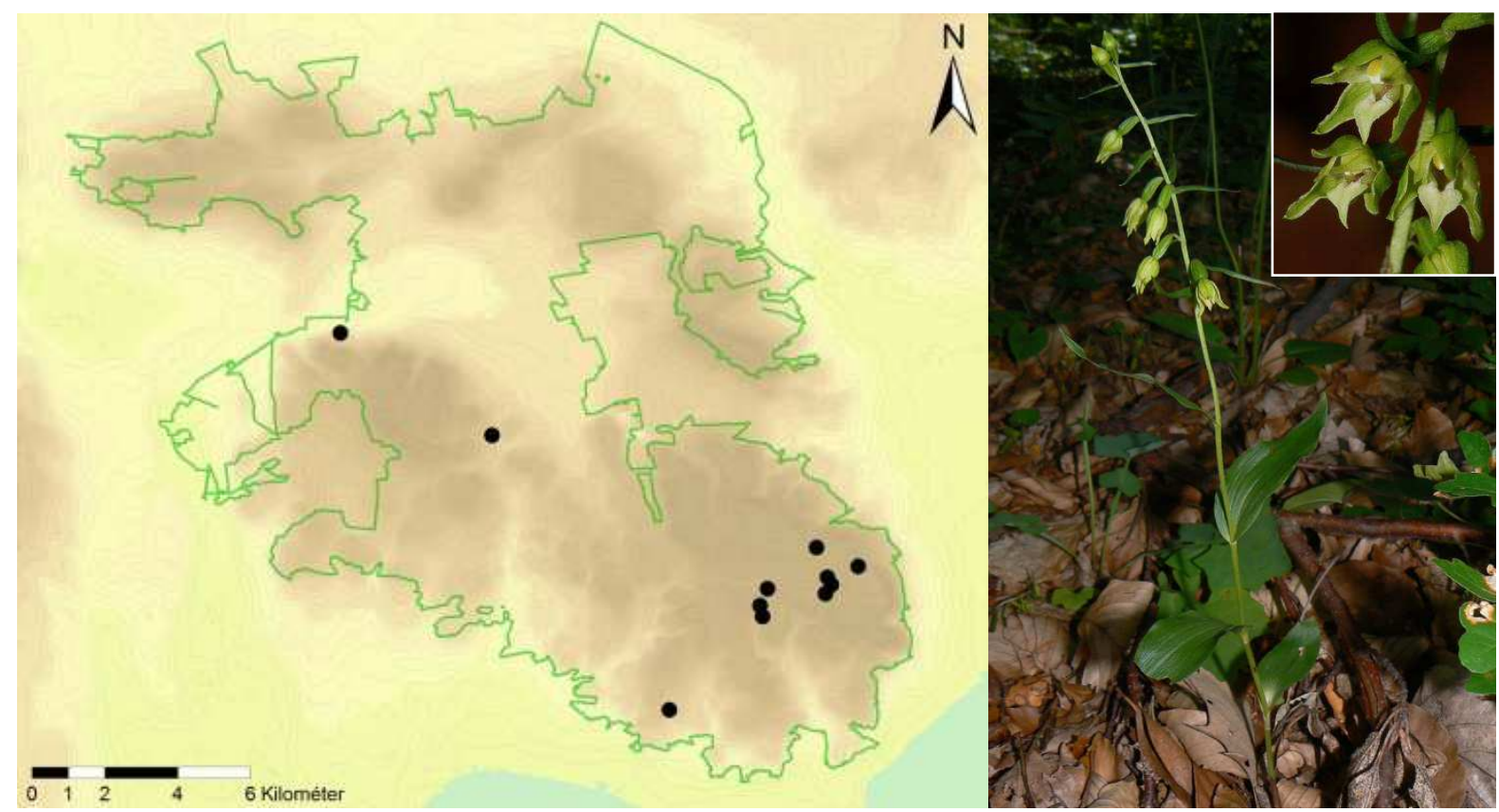

Habitus / Habit: Balatongyörök: Sárkány-erdő, 2015.07.10. Virág / Flower: Balatongyörök: Sárkány-erdő, 2015.07.10. 
Epipactis pontica Taubenheim

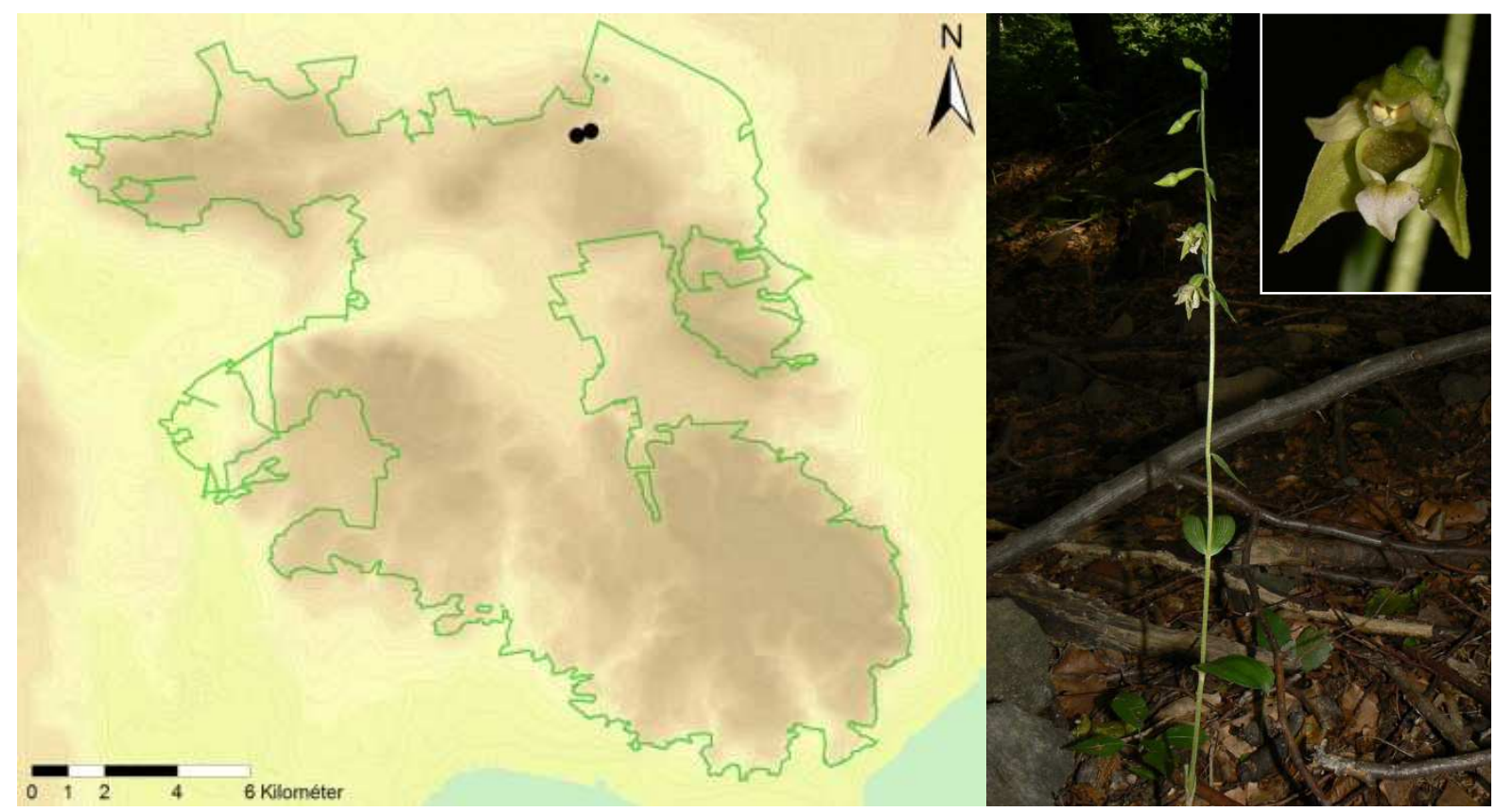

Habitus / Habit: Sümeg: Szebike-erdő, 2016.08.01.

Virág / Flower: Sümeg: Szebike-erdő, 2016.08.01.

\section{Epipactis purpurata Sm.}

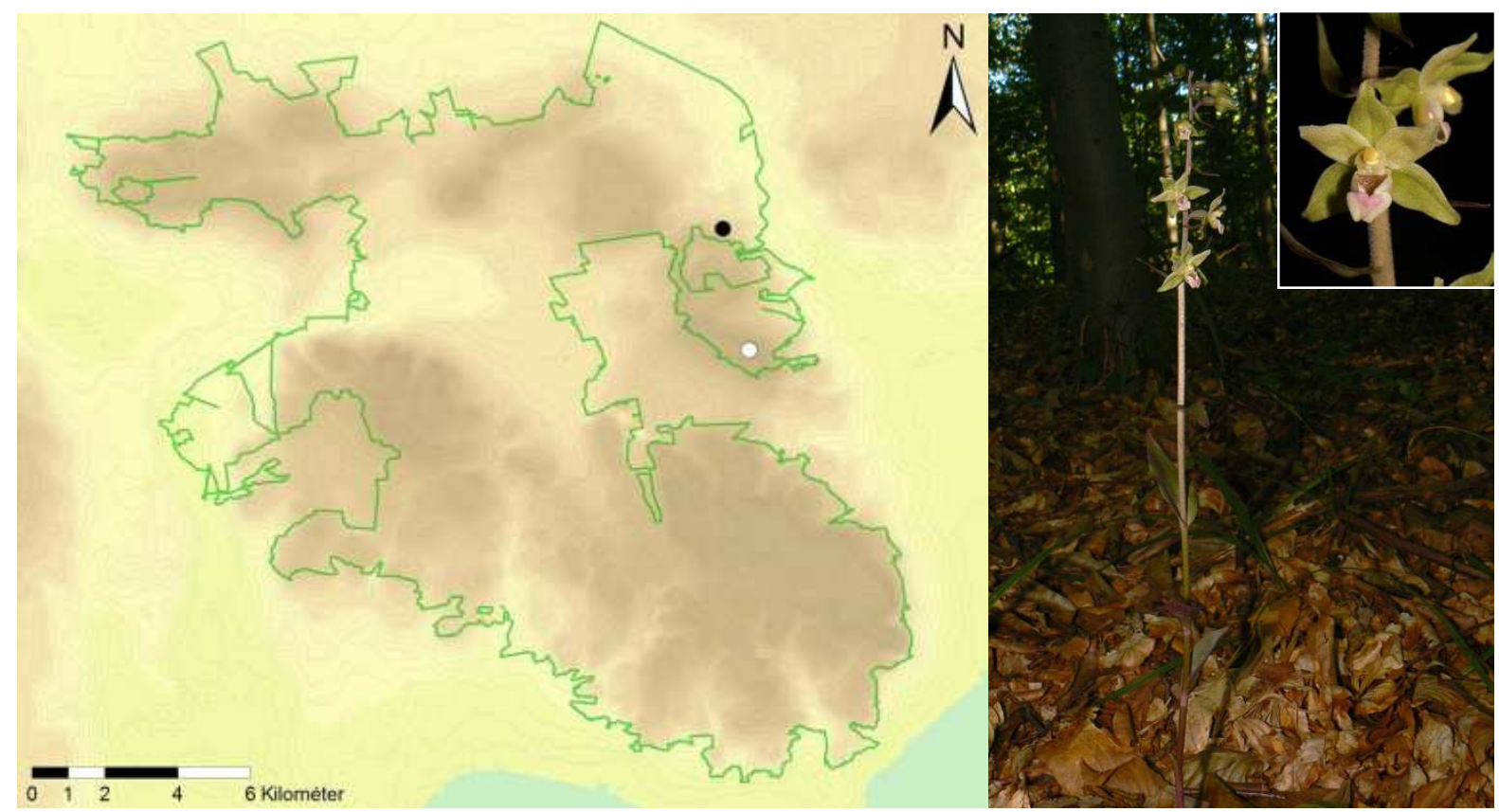

Habitus / Habit: Uzsa: Boc-hegy, 2016.07.11. Virág / Flower: Uzsa: Boc-hegy, 2016.07.11. 
Epipactis tallosii Molnár \& Robatsch

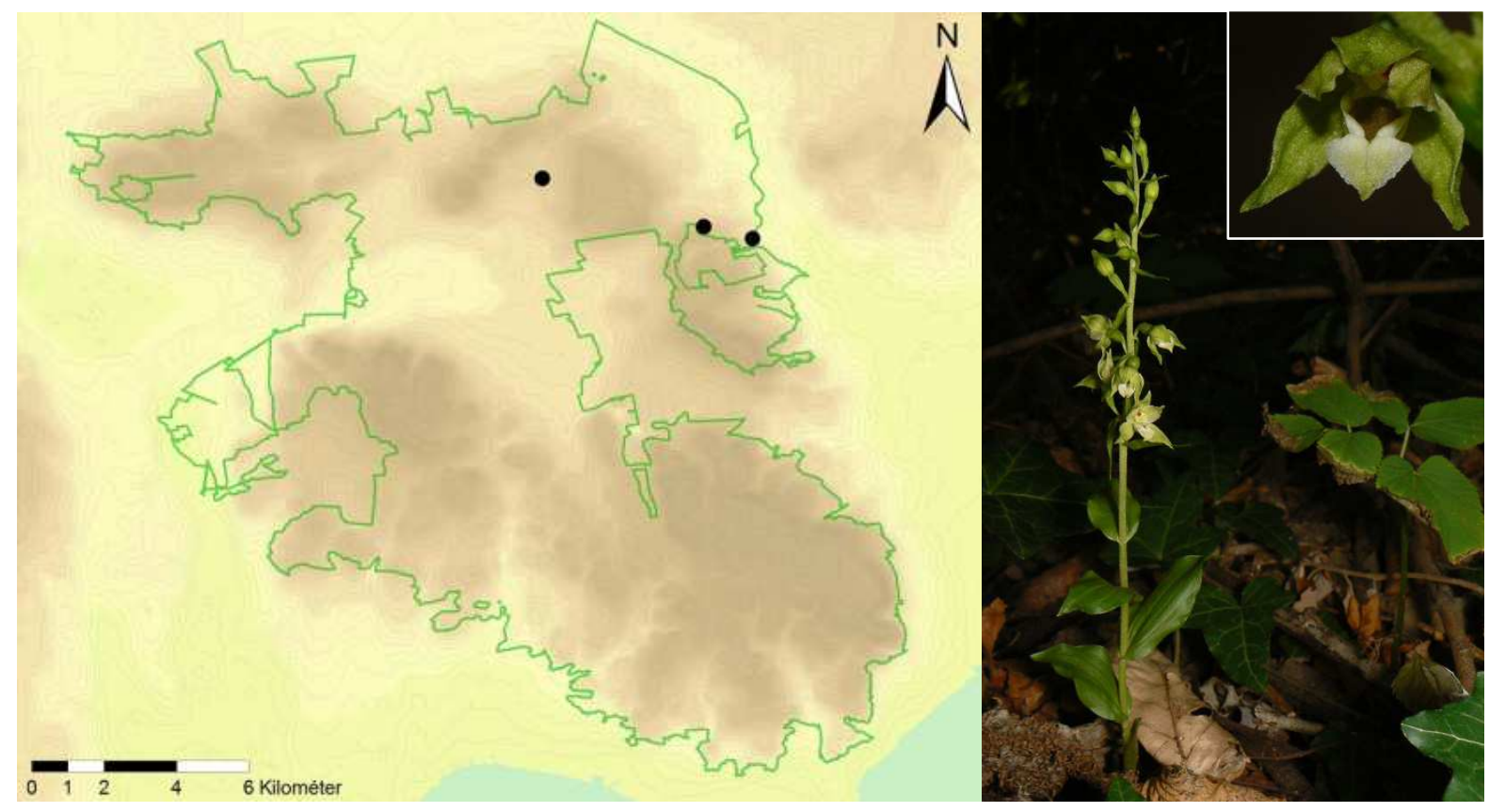

Habitus / Habit: Zalaszántó: Szebike-erdő, 2017.08.03.

Virág / Flower: Zalaszántó: Szebike-erdő, 2017.08.03.

\section{Epipactis voethii Robatsch}

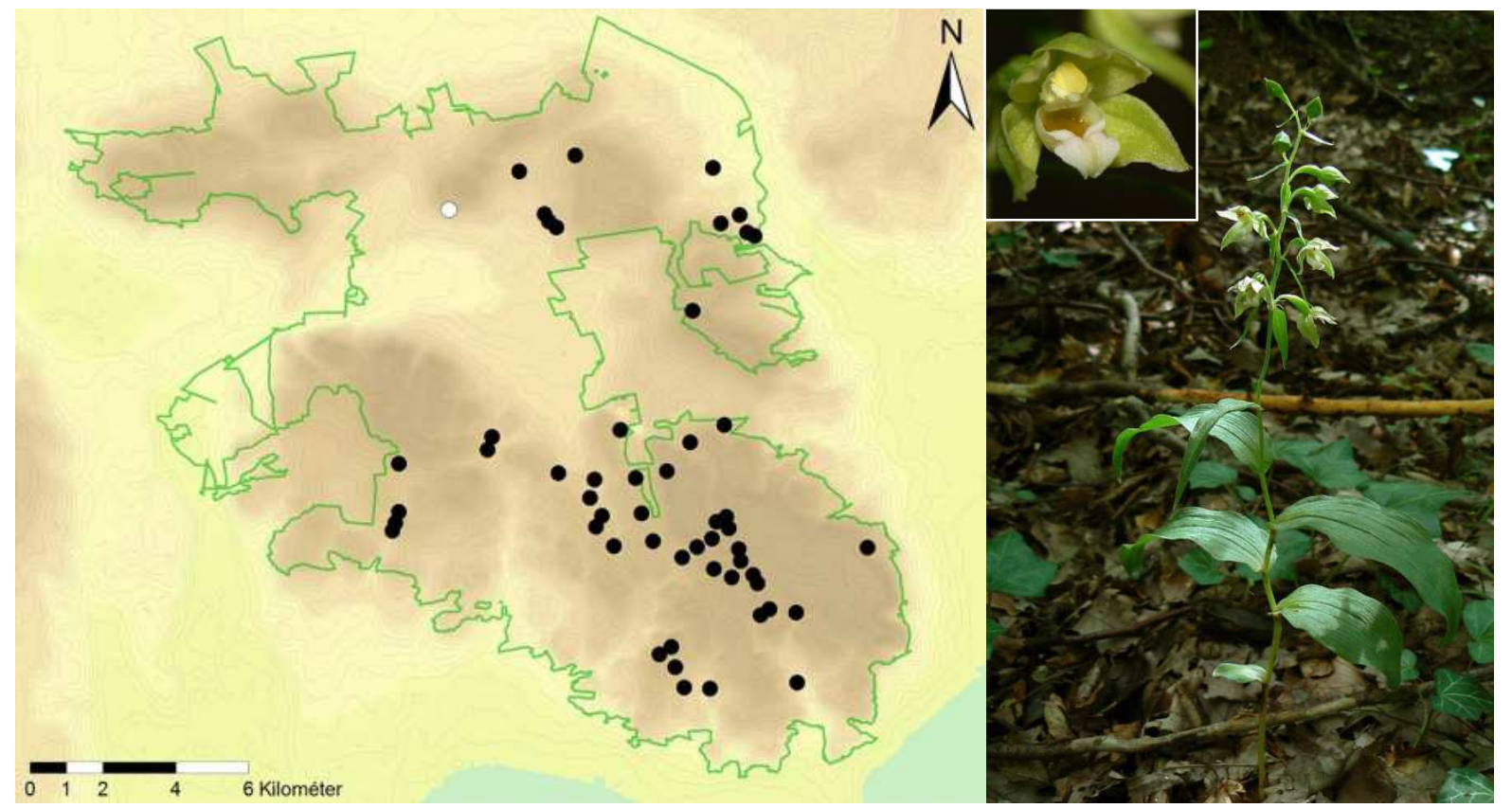

Habitus / Habit: Vállus: Görbe-tető, 2014.07.15. Virág / Flower: Vállus: Görbe-tető, 2014.07.15. 
Epipactis ×reinekei M. Bayer (E. helleborine $\times$ E. muelleri)

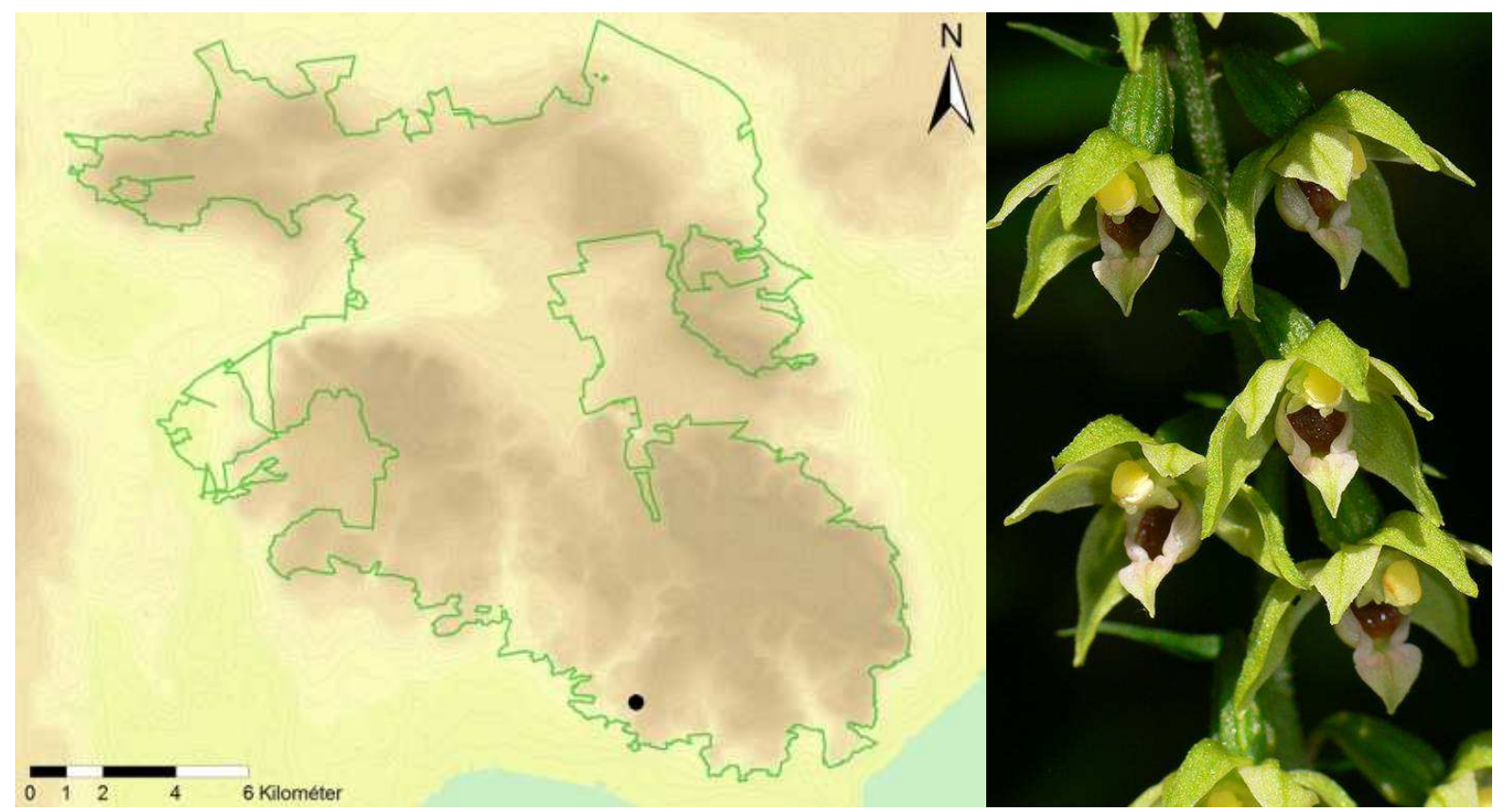

Virág / Flower: Gyenesdiás: Tüskés-lap, 2016.06.29. 